IRSH 52 (2007), pp. I IO-I Is DOI: I0.1017/S0020859006002823

(C) 2007 Internationaal Instituut voor Sociale Geschiedenis

\title{
Eurocentrism, Forced Labour, and Global Migration: A Critical Assessment
}

\author{
PrabHu P. MOHAPATRA
}

Recent historiography attempts increasingly to move beyond Eurocentrism. ${ }^{I}$ In the field of migration, Adam McKeown's article is a fine example of an attempt to put global migration in a non-Eurocentric perspective. ${ }^{2}$ Perhaps its most acute insight is in putting the paradigmatic European migration flows to the Americas in the nineteenth century at par with the mainly intra Asian (south/south-east Asian and north-east Asian) migration flows. McKeown's main target of attack is the unabashed "Euro-centrism" (or rather the "North Atlantic centrism") of much of the migration literature on the so called age of mass migration. Eurocentrism appears, at least in the way that McKeown presents it, as a set of three interrelated propositions.

In the first place, by Eurocentrism is implied the paradigmatic primacy given to transatlantic European migration over the non European migration forms, viewing the latter as quantitatively and qualitatively insignificant or atypical. Second, following from the above is the equation of European transatlantic migration with economically driven voluntary "free migration" and as a corollary, the characterization of non European migration in the same period largely as indentured or involuntary. Third is the causative primacy given to European expansion and direct European intervention and domination in the engendering and maintenance of non European migration flows. All these three forms of Eurocentrism are premised on the categorical differences and segmentation of the global migration flows between European and non European types

How have McKeown's efforts at refutation fared against these three forms of Eurocentrism? I think that the refutation is strong and convincing when demonstrating the numerical parity and sequencing of non European migration flows with the transatlantic patterns, but less convincing as regards the characterization and causation of these flows. McKeown is right in pointing out that indentured migrations were only a small part of

I. See for example, C.A. Bayly, The Birth of the Modern World (I780-1914): Global Connections and Comparisons (Oxford, 2004); Peter Gran, Beyond Eurocentrism: A New View of Modern World History (New York, 1996).

2. Adam Mckeown "Global Migration: I846-1940", Journal of World History, is (2004), pp. I5 5 - I 89 . 
the total migration flows from the non European world (Io per cent of the total migration from south Asia and a small proportion of Chinese migrants), but it is the implied inference that appears to be problematic.

First, does it mean that the rest of the non-migratory flows are necessarily "free" and without coercion? Even in the absence of (and after the abolition of) a formal indenture system, the great bulk of Asian migration flows seem not to have led to the installation of "free" and noncoerced migration but rather that indenture acted as a template for the "contract" and debt-bonded migration of free labourers. ${ }^{3}$ This, at least, is suggested by overwhelming evidence from the bulk of so-called nonindentured migration from India to south-east Asia and Ceylon. For instance, the Kangani system to Malaya or the Maistry system in Burma or the Tundu system in Ceylon- destinations which accounted for nearly 90 per cent of the total Indian migration of 30 million - functioned through systems of debt and advances, tying down labourers to particular employers through the mediation of the labour contractors. ${ }^{4}$ None of these mediating institutions, though they involved non-European agencies and were outside the purview of direct government supervision, were in any sense simply networks carved out by the migrants independent of the employers (many of them Europeans but non-Europeans too).

The key point of these migration systems was not mainly coercion at the point of recruitment (though that too was important) but the effective control exercised by employers over labourers and the lowering of wages below the market rates. Even though the bulk of these migration flows were unregulated and not supervised by the government at the point of recruitment, elaborate systems were in place for legal and extra legal coercion of the migrants at the destination (master-servant ordinances, workman's breach of contract laws and even ordinary contract laws for recovery of debts in Burma and Ceylon, for instance). McKeown argues

3. A recent survey of labour flows from the countries of the global south has delineated varieties of restrictions that severely qualified the "freedom" of non indentured migration from the countries of the south. These included, apart from direct legal restrictions, also the use of immigration laws, forced repatriation, and denial of civic rights to the migrants. Many of these restrictions aimed at tying down labourers to particular employers. Sabyasachi Bhattacharya, "Labour Forms and International Labour Flows in the Context of North-South Relationship: An Overview", in K.S. Jomo (ed.), The Long Twentieth Century (New Delhi, 2006). Sabyasachi Bhattacharya argues that the dichotomy of free and unfree labour migration retains analytical valence as long they are delinked from the implicit teleological assumptions (from unfree to free). 4. For the description and operation of the Maistry sytem in Burma, see N.R Chakravarti, The Indian Minority in Burma (London, I971); for the Kangany and Tundu system in Malaysia and Sri Lanka, see K.S. Sandhu, Indians in Malaya: Immigration and Settlement, I786-1957 (Cambridge, I969); P. Ramaswamy, "Labour Control and Labour Resistance in the Plantations of Colonial Malay", Journal of Peasant Studies, 19:3/4 (1992), pp. 87-105, 88-89; F. Heidemann, Kanganies in Sri Lanka and Malaysia, (Munich, 1992); S. Arasaratnam, Indians in Malaysia and Singapore (London, 1970); and P. Peebles, The Plantation Tamils in Sri Lanka (London, 2001). 
that coercion and violence did play a role but only in global migration flows in the mid-nineteenth century (presumably the early phase of indenture) and the I930s (Russian and Japanese forced moves), but that the great bulk of the European and non-European migration was "channelled through independent networks of friends, family and villagers".

There is thus a problematic strand of argument which, while erasing the free European/unfree Asian dichotomy reinstates another form of Eurocentrism, one that universalizes the European model of free/noncoercive/voluntary migration. A thoroughgoing critique of Eurocentrism would, I suppose, involve not just recognizing aspects of freedom in the non-European migration but also in apprehending aspects of unfreedom and coercion in the European patterns too. Heeding as one does the salutary exhortations of Lucassen and Lucassen to transcend the dichotomies of free and unfree migration plaguing migration history, it may be useful to see the patterns of migrations in both the European and non-European world as stretched out on a continuum between the free and coerced forms partaking of both and coexisting often within the same stream.' State regulations, both direct and indirect, often functioned to shift the line between these forms. McKeown, however, I admit, is sensitive to this issue as when he points out that "free " migration was itself a product of government regulations in many instances and the segmentation of free European and unfree Asian migration streams was not a product of natural conditions but a result of political intervention. ${ }^{6}$ Presumably political intervention was not only by governments but by powerful employers, again both Europeans and non-Europeans.

It is with regard to the third form of Eurocentrism, namely in the causative primacy and agency assigned to European expansion and domination, that McKeown's critique is perhaps confusing, if not weak. At several points of the article McKeown criticizes the literature for focusing too much on the European-dominated indenture migration, and critiques specially those who share the world-system perspective for viewing Asian and African migrations as "little more than a by-product of the expansion and intervention of Europe". 7 From the concurrence and contemporaneous rise of global migration flows McKeown derives the conclusion that "non Europeans were very much involved in the expansion and integration of the world economy, well beyond the direct intervention of Europe".

The last point is certainly true if we take into account non-European labour migration as a vital part of development of global economy.

5. Jan Lucassen and Leo Lucassen, "Introduction", in idem (eds), Migration, Migration History, History: Old Paradigms and New Perspectives (Berne, 1997), pp. I-38.

6. McKeown, "Global Migration", p. I73.

7. Ibid., p. I77.

8. Ibid., p. I7I. 
Absence of European domination perhaps is true to an extent for the north-east Asian migration flows (only if we discount Russia and Japan from the European and North Atlantic sphere) but certainly not true ins far as the labour flows from south Asia and the part of the Chinese movement to south-east Asia is concerned. The latter movements were mainly to areas where European presence was direct and or dominant (colonial south-east Asia, Burma, Java, and Siam etc). There is certainly something else which McKeown seems to hint at, namely the independent development of non European capital (in his case mainly the example of Chinese capitalists and entrepreneurs but we can add Indian Chettiar bankers who financed the rice cultivation in Burma) and its role in shaping labour flows. ${ }^{9}$

The point is important insofar is it redirects our attention towards the niches in the developing global economy that were captured by nonEuropean agencies, be they merchants, businessmen, money lenders, or even indigenous recruiting agents. While these were important factors, their complete independence from the hegemonic presence of European and North Atlantic capital will be difficult to establish. McKeown writes at one point with regard to the rise of global labour flows "Ultimately, European, North American, and Japanese industrialization, capital, and military power generated and dominated much of this movement" (italics mine). ${ }^{10}$ How different is this assertion from the world-systems theory of Asian migration as a "by product" of European expansion and domination, unless of course we take a purely literal and geographical meaning of Europe.

There is then a tension in McKeown's article between the idea of a global economy as causative of migration flows on the one hand and rejection of the idea of monolithic domination by Europeans of these flows. This leads to some awkward formulations as when McKeown writes "Chinese and Indian merchants, miners, and agriculturists in Southeast Asia were ultimately subjected to financial, political and military power concentrated in the hands of Europeans. [...] Chinese however were able to mobilize long-standing commercial and labor recruiting networks to develop a niche as middlemen and businessmen". ${ }^{\text {II }}$ McKeown's attempt is, of course, to confer agency to the non Europeans in order to correct the tilt towards European power but his critique would have been sharper still if asymmetries of power that were features of the global economy were seen to operate with equal force in shaping transatlantic flows. In that sense perhaps imperial social formations (with explicit asymmetries of

9. For the role of Chettiars in Burma see Chakravarti, The Indian Minority, ch. 5. Interestingly, Chettiar finance was not involved in the massive recruitment of contract labour.

ı. McKeown, "Global Migration", p. I67.

I I. Ibid., p. I 83 . 
power) rather than an idealized interdependent global economy seem to capture the context for global migration flows better.

Eurocentric perspectives segment global migration flows by positing individual choice and economic maximization motivations to migrants of European origins while denying the same to non-European migrants. McKeown rightly criticizes such segmentation of motivations and choices by focusing instead on migrant networks as enabling social formations for flows of persons information and resources. Social networks provide a possible theoretical alternative to the dichotomies of choice/force as explanations of migration flows and its specificities. McKeown's own work on Chinese migrant networks or Dona Gabaccia's work on Italian female migrants are prominent examples. ${ }^{12}$

While I am persuaded about the utility of the migrant social-network approach I also feel that the limitations of these approaches should also be kept in mind. The underlying assumption of the network approach is that they are forms of social capital that are created by a set of people linked by acquaintance, kinship, and work experiences in the process of migration for foreign employment. While focusing on the migrant and his or her connections, the network approach often tends to assume symmetrical and reciprocal relationship originating in the immediate community, village, family, or friends. This supply-side emphasis on network creation has been recently subjected to a powerful and comprehensive critique by Fred Krissman. ${ }^{13}$ Krissman argues that by underplaying the role of actors outside the network such as the employers and labour recruiters engaged by them network approaches have seriously led astray migration studies and migration policy. While his critique is focused more on the sociological and contemporary migration analysis, I think that there are salutary lessons for historians here. Networks are as much creatures of the migrants as of the employers and their agents.

Sojourning and return migration have been seen as typical examples of functioning of migrant networks. McKeown, while discussing the efficacies of migrant networks refers in passing to the general pattern of rising return migration in the transatlantic European migration streams in the latter half of nineteenth century coinciding with the shift from homesteading to industrial labour in the Americas. ${ }^{14}$ But surprisingly, he barely discusses the persistent pattern of circulation of labour in the south Asian/south-east Asian circuit. Given that his main source of data for the migration from Indian subcontinent is the magisterial work of Kingsley Davis, which prominently puts out the fact that while 30 million migrants

I2. Donna Gabaccia and Franca Iacovetta (eds), Women, Gender and Transnational Lives: Italian Workers of the World (Toronto, 2002).

I3. Fred Krissman, "'Sin Coyote Ni Patron': Why the 'Migrant Network' Fails to Explain International Migration”, International Migration Review, 3 (2005), pp. 4-44.

I4. McKeown, "Global Migration", pp. i80-i8 I. 
left the shores of India between I 834 and I 937 no less than 24 million returned during the same period. It would appear then that India was as much a labour-sending as a labour-receiving region during the age of mass migrations.

What consequences does this massive and persistent circulation of labour have for the landscape of global migration so astutely presented by McKeown? Does this present a categorical difference in comparison to the transatlantic European migration patterns? This pattern of labour circulation was not just limited to overseas migration- internal migration patterns in India were also seen to be, in large measure, circulatory during the colonial period. This in turn gave rise to the illusion of an immobile Indian society since census statistics barely captured these temporary and circular flows. Colonial reports very often noted these patterns and saw it as characteristically different to the Western pattern. I have argued elsewhere that the colonial migration paradigm by characterizing circulation as a variant of essential immobility of Indian society occluded the process by which these patterns were created by colonial policies and employer preferences. ${ }^{\text {IS }}$ It is thus not surprising that literature on overseas migration from India while replete with debates about free versus forced nature of migration has little to say about the nature of return migration. To what extent were these patterns imposed by the particular working of the global economy in south/south-east Asia?

McKeown's essay marks a major departure from the dominant Eurocentric perspectives on global migration flows, highlighting the quantitative and qualitative significance of non-European patterns of migration in shaping the evolution of global economic formations in the nineteenth and twentieth centuries. What it does, importantly, is to open new areas of investigation of the under-researched aspects of global migration studies without the blinkers of Eurocentrism. That there are limitations too in the formulation of an alternative perspective is perhaps more due to the continuing power of dominant Eurocentric frameworks and in any case detracts little from the acuity and freshness of approach in McKeown's essay. 